\title{
Ethanol Sclerotherapy for the Intractable Epistaxis
}

\author{
Yoshihiko Endo
}

\begin{abstract}
Hereditary hemorrhagic telangiectasia (HHT), also known as Osler-Weber-Rendu disease, is an autosomal dominant disease that is characterized by repetitive nasal bleeding with familial occurrence, and is frequently associated with difficulty in treating the nasal bleeding. We treated cases of refractory nasal bleeding, consisting of 4 cases of hereditary hemorrhagic telangiectasia and one case of renal cell carcinoma, metastasized to the paranasal sinus, on an out-patient basis with local injection of the esophageal varices sclerosing agent, polidocanol. Following injection sclerotherapy in all five cases, the frequency of nasal bleeding decreased. Since this procedure was able to be performed on an out-patient basis without requiring hospitalization, it was useful in improving patient QOL.
\end{abstract}

Keywords : hereditary hemorrhagic telangiectasia, nasal bleeding, polidocanol

\section{References}

1）長井今日子, 安岡義人, 古屋信彦 : オスラー病の鼻出血に どう対処するか? 一アルコール注入による硬化療法の立場 からー. JOHNS 22: 1417-1421, 2006.

2) Al-Deen $S$ and Bachmann-Harildstad G : A grading scale for epistaxis in hereditary haemorrhagic teleangectasia. Rhinology 46: 281-284, 2008.

3) Guttmacher AE, Marchuk DA and White RI Jr : Hereditary hemorrhagic telangiectasia. N Engl J Med 333: 918-924, 1995.

4) Haitjema T, Disch F, Overtoom TT, et al. : Screening family members of patients with hereditary hemorrhagic telangiectasia. Am J Med 99: 519-524, 1995.

5）斉藤孝夫：オスラー病に伴う鼻出血. 今日の耳鼻咽喉科頭 頸部外科治療指針（森山 寛，岸本誠司，小林俊光，他編）. 274-275 頁, 医学書院，東京，2008.

6）市村恵一：オスラー病に対する EBM のある治療法とは？ EBM 耳鼻咽喉科・頭頸部外科の治療 2010-2011（池田勝久, 武田憲昭, 井之口昭, 他編). 68-71 頁, 中外医学社, 東京, 2010.

7) Shovlin CL, Guttmacher AE, Buscarini E, et al. : Diagnosis criteria for hereditary hemorrhagic telangiectasia (Rendu-OslerWeber syndrome). Am J Med Genet 91: 66-67, 2000.

8）市村恵一:鼻出血 オスラー病における鼻出血とその治療. JOHNS 21: 1041-1045, 2005.

9) Braverman IM, Keh A and Jacobson BS : Ultrastructure and three-dimensional organization of the telangiectases of heredi- tary hemorrhagic telangiectasia. J Invest Dermatol 95: 422427, 1990.

10) Jameson JJ and Cave DR: Hormonal and antihormonal therapy for epistaxis in hereditary hemorrhagic telangiectasia. Laryngoscope 114: 705-709, 2004.

11）坂田雅宏：血管疾患の薬剤解説 第 14 回ポリドカノール. Vascular Lab 4: 647-649, 2007.

12) Nishikawa $K$, Nishikawa $M$ and Okita $A$ : Sclerotherapy for oral and pharyngeal hemangiomas. Pract Otol (Kyoto) 82: 579-583, 1989.

13）原順, 日吉正明, 緒方正彦 : 硬化療法が有効であった 喉頭血管腫の 1 症例。耳鼻展望 39: 393-395, 1996.

14）藤島禎弘, 黒田浩之, 天津睦郎 : 硬化療法が著効した喉頭 血管腫の 1 例. 日気管食道会報 49: 531-535, 1998.

15）河北誠二, 兵頭政光, 湯本英二, 他 : 硬化療法が奏功した 咽頭, 食道血管腫の 1 例. 日気管食道会報 51：171, 2000.

16) Yamamoto $K$ : Two cases of hemangiomas treated with injection scierotherapy by Polidocanol and photo-coagulation by KTP laser. Pract Otol (Kyoto) 94: 801-807, 2001.

17) Morais D, Millás T, Zarrabeitia R, et al. : Local sclerotherapy with polydocanol (Aethoxysklerol ${ }^{\circledR}$ ) for the treatment of Epistaxis in Rendu-Osler-Weber or Hereditary Hemorrhagic Telangiectasia (HHT): 15 years of experience. Rhinology 50 : 80-86, 2012.

18）霜 知浩, 日高康治, 柳川慎平, 他：ポリドカノールによ る血管硬化療法中に 2 度心停止を起こした小児の 1 症例. 麻酔 54: 57-59, 2005. 


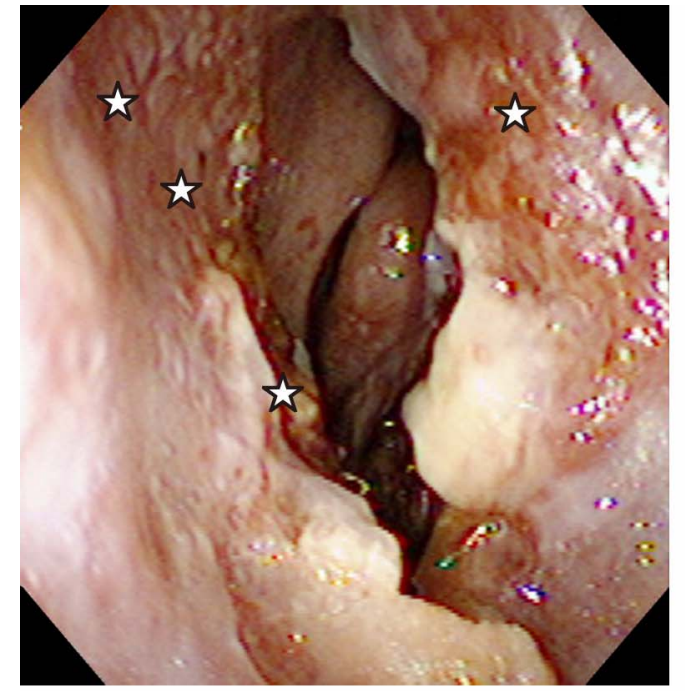

a Before the sclerotherapy

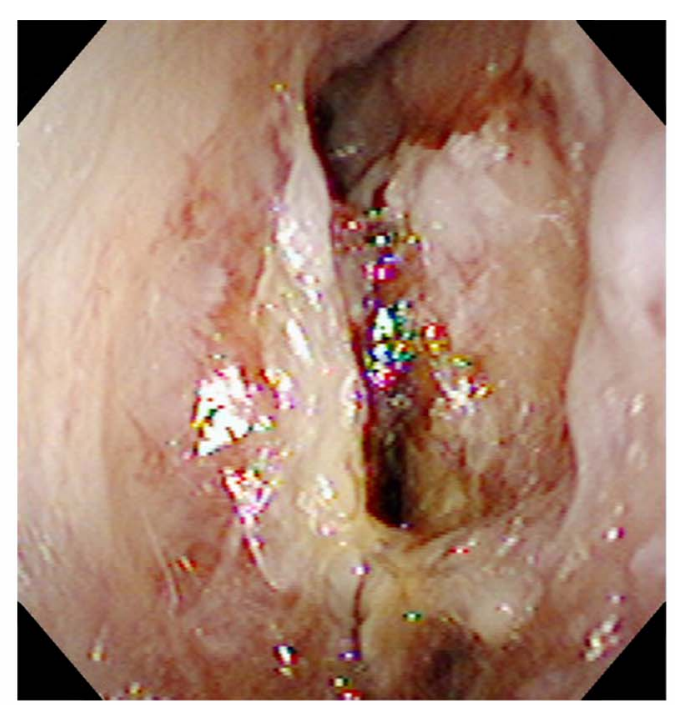

b Five month after the sclerotherapy

Intranasal findings of Case 1.

a: Polidocanol was submucosally injected at the points indicated by stars $(0.5-1.0 \mathrm{ml}$ each) b: The mucosa of the treated area has turned pale.

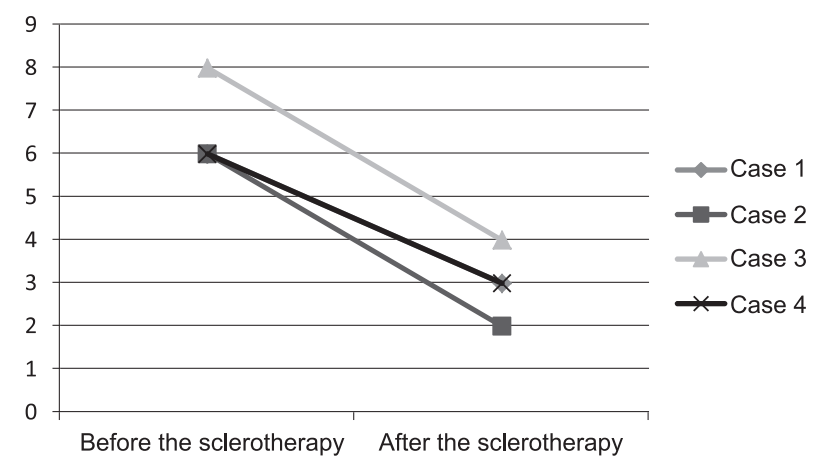

The change of the score for epistaxis (according to Al-Deen et al. ${ }^{2)}$ ) in hereditary haemorrhagic telangiectasia 